\title{
Review: Gram Negative Bacteria in Brewing
}

\author{
Paradh Ashtavinayak ${ }^{1}$, Hill Annie Elizabeth ${ }^{2}$ \\ ${ }^{1}$ Department of Alcohol Technology, Vasantdada Sugar Institute, Pune, India \\ ${ }^{2}$ The International Centre for Brewing and Distilling, Heriot-Watt University, Edinburgh, UK \\ Email: A.Hill@hw.ac.uk
}

Received 29 January 2016; accepted 19 March 2016; published 22 March 2016

Copyright (C) 2016 by authors and Scientific Research Publishing Inc.

This work is licensed under the Creative Commons Attribution International License (CC BY). http://creativecommons.org/licenses/by/4.0/

(c) (7) Open Access

\begin{abstract}
Gram negative aerobic bacteria such as Acetic Acid Bacteria, which include Acetobacter and Gluconobacter, have historically caused significant problems to brewers. Although incidences of spoilage have recently reduced as a result of improvements in beer packaging, these bacteria are still a concern in dispense systems in pub breweries, public houses and cask conditioned beers. Gram negative facultative bacteria of the genus Zymomonas can spoil primed cask conditioned beer and cider. There is a wide range of Enterobacteraeceace which are found within brewery environments and they serve as indicator microorganisms for hygiene and sanitation. Gram negative strictly anaerobic bacteria such as Pectinatus and Megasphaera have recently emerged as a significant threat due to the improvement in reduction of oxygen levels in beer and an increase in production of unpasteurised beer. Pectinatus and Megasphaera are sensitive to routine cleaning agents used in breweries, but they can survive and proliferate in biofilms eventually causing spoilage of beer. This review focuses on Gram negative aerobic, facultative anaerobic and strictly anaerobic brewery related spoilage bacteria.
\end{abstract}

\section{Keywords}

Gram Negative Bacteria, Beer Spoilage, Pectinatus, Megasphaera, Acetic Acid Bacteria

\section{Introduction}

Beer is microbiologically stable due to several intrinsic microbiological properties. Firstly, it has low $\mathrm{pH}$ (pH 3.8 - 4.7) and the ethanol content can vary from $0.5 \%$ to $10 \%(\mathrm{w} / \mathrm{w})$. Ethanol causes cellular membrane damage in addition to denaturation of proteins, interfering with metabolism and causing cell lysis of bacteria [1] [2]. Hop bitterness compounds (iso- $\alpha$ acids) are present at approximately 17 - 55 ppm and they can cross the cytoplasmic membrane of bacteria in their intact form. These compounds act as a protonophores dissipating the transmembrane $\mathrm{pH}$ gradient, which inhibits growth of hop sensitive microorganisms [3] [4]. The presence of low oxygen 
concentration (less than $0.1-0.3 \mathrm{ppm})$ and relatively high $\mathrm{CO}_{2}(0.5 \% \mathrm{w} / \mathrm{v})$, makes beer almost anaerobic [5]. Beer also has extremely low levels of nutrients as most of the fermentable sugars are utilised by brewing yeast during fermentation. All of these factors make propagation of bacterial contaminants difficult in beer [6].

In addition, hurdles for bacterial contaminants are provided by process conditions such as wort boiling, pasteurisation and sterile filtration [7]-[9]. In some exceptional cases survival of some food spoilage microorganisms such as Bacillus cereus and Bacillus licheniformis has been reported in home brewed beer [10]. However such incidents in commercial brewing have not been reported.

Beer spoilage microorganism can be broadly classified into Gram positive bacteria, Gram negative bacteria and wild yeasts. Gram positive beer spoilage bacteria are regarded as the most hazardous for modern breweries [11]-[13], which mainly include lactic acid bacteria belonging to the genera Lactobacillus and Pediococcus [14]. Other less significant Gram positive bacteria capable of growth in beer include species belonging to genera Leuconostoc, Micrococcus and some Staphylococcus species [15] [16].

Gram negative beer spoilers mainly include anaerobic bacteria belonging to genera Pectinatus, Megasphaera, Selenomonas and Zymophilus. Other significant Gram negative aerobic and facultative anaerobe beer spoilers belong to genera Acetobacter, Zymomonas, Selenomonas, and Obesumbacterium. Certain Enterobacteriaceae such as Rahnella and Hafnia have also been reported in brewing environments [15]-[17]. Wild yeasts in brewing are generally described as "yeast strains which are not deliberately introduced and grow uncontrolled in the brewing process" [18]. Microbial contaminants exposed to brewing raw materials and beer at different stages are shown in Figure 1.

This review focuses on Gram negative aerobic, facultative anaerobic and strictly anaerobic brewery related spoilage bacteria. Important categories of Gram negative beer spoilage bacteria are comprehensively described in this review. The review deals with current taxonomic status, metabolic aspects, beer spoilage ability and detection methods utilised for these bacteria.

\section{Gram Negative Aerobic and Facultative Anaerobic Bacteria in Brewing}

Only a few Gram negative bacteria have been found to be responsible for beer spoilage and these bacteria can be

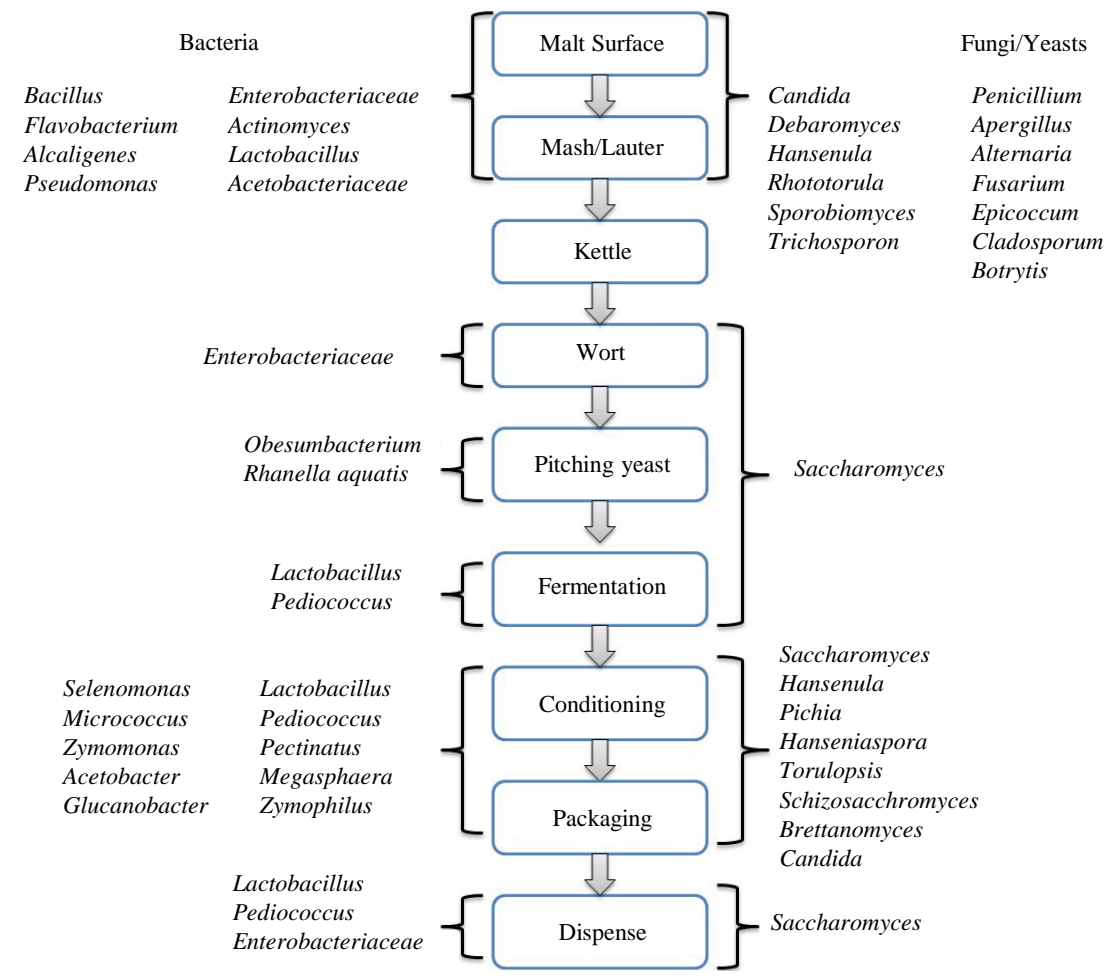

Figure 1. Microbial contaminants exposed to brewing raw material and beer at different stages (Originally adapted from [19] [20] [112]). 
divided into two categories. The first category includes aerobic and facultative anaerobic bacteria such as Acetic Acid Bacteria, Zymomonas and certain Enterobacteriaceae species. The second category is the anaerobic beer spoilers belong to genera Pectinatus, Megasphaera, Zymophilus, Selenomonas and Propionispora. Pectinatus and Megasphaera are regarded as the most important beer spoilage bacteria, mainly in unpasteurised beer. Spoilage effects of Gram negative bacteria are shown in Table 1.

\subsection{Acetic Acid Bacteria}

Acetic Acid Bacteria (AAB) are industrially important as they can produce organic acid by oxidising sugar to ethanol then to organic acid, principally acetic acid. Gluconobacter are used for production of vinegar commercially. AAB bacteria are also used in various biotechnological applications [21] [22]. AAB are Gram-negative, aerobic, non-spore forming bacteria having ellipsoidal to short rod-shaped cell morphology. They occur individually, in pairs or in chains. AAB can be motile in nature and flagella arrangement may vary from peritrichous to polar [21]. AAB bacteria are also important due to their spoilage effect on alcoholic beverages such as wine and beer [23]. Beer spoilage AAB form a pellicle on the surface with cloudiness in beer containing oxygen. Due to formation of acetic acid, beer tastes sour to vinegary [24] [25]. AAB are strictly aerobic bacteria but some of the AAB isolated from draught beer have been reported to be micro-aerotolerant [26].

At present AAB taxonomically belongtofamily Acetobacteraceae [27] of class Alpha Proteobacteria. Two genera out of 15 validated AAB, namely Acetobacter and Gluconobacter, are reported to be associated with brewery environments [26]. Amongst the validated species of AAB, ten species of Acetobacterhave been associated with brewing environmentsand A. aceti, A. liqueficiens, A. pastorianus and A. hansii are frequently found inbreweries [26] [28]. Only one species of Gluconobacter (G. oxydans) has been reported to be regularly associated with brewing environments [26] [29] [30]). However Gluconobacter cerevisiae has also been reported [31].

Production of acetic acid from oxidation of ethanol is asignificant characteristic of Acetobacter and Gluconobacter. The process is catalysed by cytoplasmic membrane bound enzymes alcohol dehydrogenase and aldehyde dehydrogenase for production of acetaldehyde from ethanol and acetaldehyde to acetic acid respectively [32]. Under acidic conditions the alcohol dehydrogenase activity of Acetobacter is comparatively more stable to the activity in Gluconobacter which results in more acetic acid production by Acetobacter [33]. A variety of carbohydrate sources such as arabinose, fructose, galactose, mannitol, mannose, ribose, sorbitol and xylose are utilised by AAB through the hexose monophosphate pathway [34], Embden-Meyerhof-Parnas (EMP) and EntnerDoudoroff (ED) pathway [35].

$\mathrm{AAB}$ occur throughout the brewing process (see Figure 1). But due to elimination of oxygen throughout, there has been significant reduction in spoilage incidents due to AAB. AAB are highly tolerant to hop bitterness compounds and can survive in high concentrations of ethanol $(>10 \% \mathrm{v} / \mathrm{v})$ [28]. ABB prevail in initial stages of biofilm formation in brewery environments [36]. AAB are more commonly associated with dispense lines in pubs and public houses due to higher oxygen and high temperature at some stages in beer dispense [37] [38]. Frequent incidents of beer spoilage in draught beer kegs have been reported [24]. Acetobacter and Gluconobacter have also been occasionally found in samples from beer fermentation and storage tanks [39]. AAB are still prevalent in cask conditioned and barrel aged beers [40].

As described, AAB bacteria produce sourness in beer due to formation of acetic acid. Gluconobacter in the beer leads to formation of a pellicle on the surface with cloudiness in beer containing oxygen. Some strains of Gluconobacter produced extran and levan leading to formation of ropiness in the beer with high viscosity [41]. Gluconobacter oxydans contains various membrane-bound dehydrogenases, these enzymes rapidly metabolise sugars or sugar acids from the sugar rich substrate and can even survive in high sugar substrates [42]. Gluconobacter are often isolated from soft drinks and various fruit based products [42] [43].

\subsection{Genus Zymomonas}

Zymomonas are short plump rods which occur singly, in pairs and sometimes in chains or rosettes [26]. These bacteria are Gram-negative, non-endospore forming and catalase positive. Zymomonas are aerotolerant and facultatively anaerobic in nature. Zymomonas are ethanol tolerant (below $10 \%$ ethanol v/v) and grow optimally at $\mathrm{pH}$ above 3.4 and temperature of $25^{\circ} \mathrm{C}-30^{\circ} \mathrm{C}$ [44]. These bacteria can utilise monomer sugars such as glucose and fructose but are not able to metabolise maltose and maltotriose [26] [45]. Zymomonas species are often isolated as a source of spoilage microorganisms from various traditional alcoholic beverages all over the world. 
Table1. Spoilage effects and metabolic products produced by gram negative beer spoilage bacteria.

\begin{tabular}{|c|c|c|c|c|}
\hline Bacteria & $\begin{array}{l}\text { Occurrence in brewery } \\
\text { environments }\end{array}$ & $\begin{array}{l}\text { Off flavour/aroma } \\
\text { and odour }\end{array}$ & $\begin{array}{l}\text { Visual } \\
\text { poilage } \\
\text { effects }\end{array}$ & Metabolic products \\
\hline \multicolumn{5}{|c|}{ Acetic acid bacteria [2] [21] [24] [26] } \\
\hline Acetobacter & $\begin{array}{l}\text { Wort, beer dispenses and cask } \\
\text { condition ales and barrel aged } \\
\text { ales, brewery biofilm. }\end{array}$ & Sour, vinegar & $\begin{array}{l}\text { Haze, } \\
\text { Ropiness }\end{array}$ & Acetic acid \\
\hline Glucanobacter & $\begin{array}{l}\text { Wort, beer dispense and cask } \\
\text { condition ales }\end{array}$ & Sour, vinegary & Haze & Acetic acid, acetate \\
\hline Zymomonas & $\begin{array}{l}\text { Primed beers } \\
\text { (not found in lagers) }\end{array}$ & $\begin{array}{l}\text { Fruity, rotten apple, } \\
\text { rotten egg, } \\
\text { sulphudic }\end{array}$ & $\begin{array}{l}\text { Haze } \\
\text { Ropiness }\end{array}$ & Acetaldehyde and $\mathrm{H}_{2} \mathrm{~S}$ \\
\hline \multicolumn{5}{|c|}{ Enterobacteriaceae [26] } \\
\hline Obesumbacterium & $\begin{array}{l}\text { Pitching yeast and fermenting } \\
\text { wort }\end{array}$ & Parsnip, sulphury & Haze & $\begin{array}{l}\text { Dimethyl sulphides (DMS), diacetyl, } \\
\text { higher alcohols and N-nitrosamines, } \\
\text { acetoin }\end{array}$ \\
\hline Citrobacter & Brewing liquor, fermenting wort & Parsnip, sulphury & & $\begin{array}{l}\text { Dimethyl sulphides (DMS), diacetyl, } \\
\text { lactic acid, acetaldehyde }\end{array}$ \\
\hline Rahnella & $\begin{array}{l}\text { Pitching yeast, Early stages of } \\
\text { fermentation (wort) }\end{array}$ & Fruity, sulphury, & - & $\begin{array}{l}\text { Dimethyl sulphides (DMS), diacetyl, } \\
\text { methyl acetate, ethyl acetate }\end{array}$ \\
\hline Klebseilla & Fermenting wort, biofilm & Unpleasant odour & - & $\begin{array}{l}\text { 4-vinylguaicol, Dimethylsulphides } \\
\text { (DMS), diacetyl. }\end{array}$ \\
\hline \multicolumn{5}{|c|}{ Obligatory anaerobes [72] [76] [77] [99] } \\
\hline Pectinatus & $\begin{array}{l}\text { Low alcohol unpasteurised beer, } \\
\text { beer filling area, biofilm }\end{array}$ & $\begin{array}{l}\text { Rotten egg, } \\
\text { unpleasant odour }\end{array}$ & Turbidity & $\begin{array}{l}\text { Acetic acid, propionic acid, lactic } \\
\text { acid, succinic acid, } \mathrm{H}_{2} \mathrm{~S} \text {, acetoin, } \\
\text { methyl mercaptan and other sulphur } \\
\text { compounds }\end{array}$ \\
\hline Megasphaera & $\begin{array}{l}\text { Low alcohol, unpasteurised beer, } \\
\text { beer filling area, biofilm }\end{array}$ & Unpleasant odour & Turbidity & $\begin{array}{l}\mathrm{H}_{2} \mathrm{~S} \text {, butyric acid, isobutyric acid, } \\
\text { caprioc acid, valeric acid, isovaleric } \\
\text { acid. }\end{array}$ \\
\hline Selenomonas & Pitching yeast & Unpleasant odour & Turbidity & Acetic, lactic, and propionic acids. \\
\hline Zymophilus & pitching yeast or brewery waste & Unpleasant odour & Turbidity & Acetic acid and propionic acid \\
\hline
\end{tabular}

References: [21] [24] [26] [72] [76] [77] [99].

These bacteria are found on the glucose rich sugarcane juice, agavesapand palm trees as a naturally occurring fauna [46]. Zymomonas is a biotechnologically important microorganism for industrial production of fuel ethanol [47] [48]. Genus Zymomonas belong to family: Sphingomonadaceae in Phylum: Proteobacteria. Zymomonas has only one species, cited as Zymomonasmobilis formerly known as Achromobacter anaerobium, isolated from beer [49]. Zymomonas has also been synonymously described as Saccharomonaslindneri and Pseudomonaslindneri [41]. At present, Z. mobilis has three sub species namely: Z. mobilis subsp. Pomaceae [50], Z. mobilis subsp. Mobilis [51] [52] and Z. mobilis subsp. francensis [46]. Out of the three validated species only Z. mobilis subsp. mobilis is reported to be a beer spoiler [26].

Spoilage due to Zymomonas is quite a common problem in ciders; a motile rod shape bacterium responsible for sick cider has been well studied. The original source of contamination by Zymomonas species in the brewery and cider house is still unknown. Soil is suggested to be the possible source of contamination in beer [24] [53], as incidents of $Z$. mobilis contamination are linked to times of construction of new facilities and excavation in breweries [24]. Z. mobilis subsp. mobilis has also been reported to prevail in public houses, well water sources, soil from brewery environments and bottling lines [51]. Z. mobilis contaminated beer has a fruity aroma (rotten apple due to production of acetaldehyde) which rapidly progresses to sulphidic and rotten egg aroma in spoiled beer.

The contamination incidents due to Zymomonas are limited to ales supplemented with primed sugar and spoilage problems due to these bacteria have never been encountered in lager beers [19] [54]. Z. mobilisis a distinctive aerobic microorganism as it utilises the Entner Doudoroff (ED) pathway anaerobically instead of the Embden Meyerhof Parnas (EMP) pathway. Z. mobilis uses the pathway to ultimately ferment glucose, fructose and sucrose to ethanol and $\mathrm{CO}_{2}$ [51] [55]. Zymomonas is unable to utilise lactose, maltose and cellobiose due to the lack of genes responsible for production of enzymes necessary for metabolism of these sugars [55]. 


\subsection{Enterobacteriaceae Related to Brewery Environments}

The Enterobacteriaceae [56] [57] is a large family of Gram negative facultatively anaerobic bacteria belonging Class: Gammaproteobacteriaof Phylum Proteobacteria. Within the family Coli form bacteria broadly comprise Enterobacteriaceae species belonging to genera Enterobacter, Klebsiella, Escherichia, Hafnia and certain strains of Citrobacter which are able to utilise lactose with gas and acid formation at $35^{\circ} \mathrm{C}-37^{\circ} \mathrm{C}$ within 48 hours [58]. Coli form bacteria are indicators of the hygienic conditions and level of sanitation in breweries. Presence of Coli forms in water is related toincompetence in process water treatment. These bacteria can be introduced into wort through contaminated water or contact with external fluids through connecting pipes [16].

\subsubsection{Obesumbacterium spp.}

Obesumbacterium proteus belongs to the family Enterobacteriaceae and is an extensively studied beer spoilage microorganism. O. proteus shows negative reaction to Gram staining and is aerobic or facultatively anaerobic. Morphologically it is a short rod but it has also been reported to show pleomorphic rod morphology in the presence of yeast in fermenting wort [59]. O. proteus shows a negative reaction to the oxidase test and a delayed and weak positive reaction to the catalase test. The bacterium can reduce nitrate to nitrite in fermenting wort [60].

The genus Obesumbacterium contains only one species, O. proteus, and it was isolated as a contaminantwithin the brewing yeast culture. Formerly $O$. proteus was classified as Flavobacterium proteus [49]. Later this bacterium was assigned to the genus Obesumbacterium and $O$. proteus as a sole type strain within the genus [61] [62]. As a result of detailed taxonomic studies conducted by Priest et al. [63], the genus Obesumbacterium was assigned to the family Enterobacteriaceae. Further O. proteus biogroup-1 are supposed to be more closely related to Hafnia alvei, a common pathogenic bacterium, while the strains from biogroup-2 are commonly encountered in brewery environments and have not been reported from any other source [60] [63] [64]. Further, $O$. proteus biogroup-2 was assigned to a new genus Shimwellia and the species as Shimwellia pseudoproteus [60].

$O$. proteus is found in pitching yeast and fermenting wort, and it has never been reported in beer due to its inability to grow below $\mathrm{pH}$ 3.9. O. proteusis encountered in initial stages of fermentation where it competes with yeast for nutrients resulting inaslower rate of fermentation. $O$. proteus also produces metabolites such as dimethyl sulfoxide (DMS), acetoin, lactic acid, propanol, isobutanol and 2, 3-butandiaol. DMS imparts parsnip flavour to contaminated beer [59]. The threshold of detection of DMS is lower than $30 \mu \mathrm{g}$ of DMS/L while $O$. proteus produce 14 - $18 \mu \mathrm{g}$ of DMS/L in single pitching. Due to the practice of re-pitching, the concentration of these bacteria will eventually rise to produce off flavour above threshold levels [42]. Some Enterobacteriaceae especially $O$. proteus can produce $\mathrm{N}$-nitrosamine compounds which are carcinogenic in nature [65]. Concentration of N-nitroso compounds (ATNCs) should be monitored in beer to less than (20 $\mu \mathrm{g} / \mathrm{L})$ and as these compounds pose a health risk [66] it is important to monitor levels of Enterobacteriaceae species related to brewery environments.

\subsubsection{Other Brewery Related Coliforms}

Brewery related Enterobacteriaceae serve as hygiene indicator microorganisms and are not normally able to grow in finished beer. They may, however, grow during the initial stages of the brewing process, causing unwanted off-flavours in the final product [67]. Coli forms such as Citrobacter freundii, Rahnella aquatilis, Klebsiella oxytoca and Klebsiella terrigena have been reported in unfermented and fermenting wort [16]. Citrobacter freundii is a facultative anaerobe, morphologically motile, slender, short rod occurring singly and in pairs and is catalase positive [26]. These bacteria are inhibited by ethanol and only occur during early stages of fermentation and rarely occur in beer. The effect is reported to produce an enhanced fermentation rate and production of diacetyl, lactic acid, acetaldehyde and dimethyl sulphide (DMS). K. terrigena and K. oxytoca have been reported in brewery environments [16]. Klebsiella species are important as they produce phenolic off flavours due to formation of 4-vinylguaiacol produced from decarboxylation of ferulic acid present in the wort similar to some wild yeast. K. terrigena also produces high concentrations of acetoin and 2, 3-butanediol through the 2, 3 butanediol pathway by enhanced formation of $\alpha$ acetolactate. All genes for the 2, 3 butanediol pathway in K. terrigena are located on a single operon and production of 2, 3 butanediol is related to amino acid synthesis, $\mathrm{pH}$ and presence of oxygen [68]. Rahnella aquatilis (formerly Enterbacteragglomer) has been isolated from various sources such as soil, water, food, plant material and occasionally from clinical specimens [69]. In brewing environments it has been reported as a contaminant in top fermenting yeast and fermented wort [70] [71]. R. aquatilis 
has been reported to affect the fermentation rate initially but its growth is effected by ethanol during later stages of fermentation. The aroma and flavour of contaminated beer has been typically described as fruity, milky and sulphury due to production of dimethylsulphide (DMS), acetaldehyde, methyl acetate and diacetyl in fermenting wort [71]. Due to its ability to survive through the beer fermentation process and accumulate in pitching yeast $R$. aquatilis can be termed as a potential beer spoiler [70].

\section{Gram Negative Strictly Anaerobic Bacteria in Brewing}

Due to implementation of effective cleaning and sanitation procedures in modern breweries and effective removal of oxygen from post fermentation processes, spoilage due to aerobic Gram negative bacteria such as Acetobacter and Glucanobacter has been significantly reduced [6]. However the strictly anaerobic bacteria such as Pectinatus and Megasphaera have emerged as a potential spoilage threat to microbiological stability of beer. General characteristics of Pectinatus and Megasphaera are given in Table 2.

\subsection{Pectinatus}

Pectinatus was reported as a new genus of Gram negative, catalase negative, motile, obligate beer spoilage bacteria in the 1970s when it was first isolated from a brewery in the United States in unpasteurized beer stored at $30^{\circ} \mathrm{C}$ [72]. P. cerevisiiphilus was later isolated from breweries in Finland, Germany, Norway, Japan, Spain, Netherlands, Sweden and France [73]-[75]. During the 1990s in an extensive taxonomic study of anaerobic rods isolated from breweries, a second species of the genus Pectinatus was identified as $P$. frisingensis [76].

Pectinatusfrisingnesis can fermentcellobiose, inositol and $\mathrm{N}$-acetyl glucosamine but it cannot utilise xylose and melibiose which can be utilised by P. cervisiiphilus [76]. A third brewery related Pectinatus species, $P$. haikarae was identified on the basis of 16S rRNA gene sequence analysis and differences in sugar utilization, catalase activity, antibiotic resistance and temperature tolerance compared to the two previously characterised species [77]. P. portalensis was also proposed as a relatively fast growing, coccoid shaped, new species isolated from the waste water treatment plant of a winery [78], but 16S RNA gene sequencing analysis and phenotypical characteristics of $P$. portalensis type strains CECT $5841^{\mathrm{T}}$ and LMG $22865^{\mathrm{T}}$ did not validate as a new species and these strains were identified as cocci shaped Enterococcus faecalis [79].

The genus Pectinatus currently comprises three brewery related species: $P$. cerevisiiphilus [72], P. frisingensis [76] and P. haikarae [77]. The growth of Pectinatus species is accompanied by extensive turbidity and an offensive aroma similar to rotten eggs due to the production of various fatty acids, hydrogen sulphide and methyl mercaptan [72] [73]. All three species have been isolated from brewery environments and hence the genus

Table 2. General characteristics of beer spoilage Pectinatus and Megasphaera species.

\begin{tabular}{|c|c|c|c|c|c|c|}
\hline \multirow{2}{*}{ Characteristics } & \multicolumn{6}{|c|}{ Bacterial species } \\
\hline & 1 & 2 & 3 & 4 & 5 & 6 \\
\hline Inhabit & $\begin{array}{l}\text { spoiled } \\
\text { beer }\end{array}$ & brewery bottling hall & spoiled beer & spoiled beer & spoiled beer & spoiled beer \\
\hline $\begin{array}{c}\mathrm{G}+\mathrm{C} \text { Content } \\
(\%)\end{array}$ & 38.6 & 39.1 & 38.4 & $42.4-4.8$ & 40.5 & 43.1 \\
\hline $\begin{array}{l}\text { Width x Length } \\
\qquad(\mu \mathrm{m})\end{array}$ & $0.7-1.0-30$ & $0.6-0.8 \times 3-50$ & $0.7-0.9 \times 3-50$ & $1.5-2.1$ & $\begin{array}{c}1.2-1.9 \times 1 \\
-1.4\end{array}$ & $\begin{array}{c}1-1.4 \times 0.8 \\
-1.2\end{array}$ \\
\hline \multicolumn{7}{|l|}{ Temperature $\left({ }^{\circ} \mathrm{C}\right)$} \\
\hline Range & $10-45$ & $15-30$ & $15-37$ & $10-37$ & $10-30$ & $10-30$ \\
\hline Optimum & 30 & 30 & 30 & 30 & 30 & 30 \\
\hline \multicolumn{7}{|l|}{$\mathrm{pH}$} \\
\hline Range & $3.5-8.5$ & $4.0-8.0$ & $3.5-8.0$ & - & - & - \\
\hline Optimum & 6.5 & 7 & 6.5 & - & - & - \\
\hline catalase activity & - & + & - & - & - & - \\
\hline Spoilage ability & absolute beer spoiler & potential beer spoiler & absolute beer spoiler & $\begin{array}{c}\text { potential } \\
\text { beer spoiler }\end{array}$ & $\begin{array}{c}\text { potential } \\
\text { beer spoiler }\end{array}$ & $\begin{array}{c}\text { potential } \\
\text { beer spoiler }\end{array}$ \\
\hline
\end{tabular}

1) Pectinatus cerevisiiphilus; 2) Pectinatus frisingensis; 3) Pectinatus haikarae; 4) Megasphaera cerevisiae; 5) Megasphaera paucivorans; 6) Megasphaera sueceinsis; References: [77] [88]. 
Pectinatus was considered to be brewery specific. Recently two new species of Pectinatus have been recovered from salty pickle waste water, namely P. brassicae [80] and P. sottacetonis [81]. P. brassicae may be differentiated from other Pectinatus species based on high salt tolerance [80]. The non-beer Pectinatus such as $P$. brassicae and $P$. sottacetonis have not been studied for beer spoilage ability.

Previously, Gram negative anaerobic bacteria belonging to the genus Pectinatus were affiliated to sub branch sporomusa in the family Acidamincocaceae of class Clostridia [82]-[84]. However in 2010, a new class Negativicutes bacteria having a Gram negative cell wall, was proposed within the phylum Fermicutes along with a new order, Selenomonadales [85] which has changed the taxonomic status of the genus Pectinatus affiliating it to class-Negativicutes [85], Order-Selenomonadales [85], Family-Veillonellaceae [85] [86], Genus Pectinatus [72] [76] [77] [80]. P . cerevisiiphilus, even though $P$. frisingensis is suggested to be descended from the latter based on cross reactivity experiments of flagella antibodies [87]. $P$. haikarae which is capable of growing at slightly lower temperature than the other Pectinatus species is suggested to be diverged from $P$. cerevisiiphilus as a result of better acclimatisation to brewery environments. P. haikarae is also catalase positive unlike $P$. cerevisiiphilus and $P$. frisingensis which may provide better survival in aerobic brewery environments [88]. Scanning Electron Micrographs (SEM) of Pectinatuscerevisiiphilus and Pectinatusfrisingensis and Megasphaera cerevisiae are shown in Figure 2.

Most Pectinatus species have been isolated from beer and brewery environments but their natural environment and source of contamination are not well understood [89]. It has been found that several sources of contamination can be identified in the same brewery. $P$. cerevisiiphilus and $P$. frisingensis have been extensively studied and $P$. frisingensis has been more frequently held responsible for beer spoilage incidents compared to $P$. cerevisiiphilus in unpasteurised beer [75] [90] [91]. Along with unpasteurised beer Pectinatus species have also been isolated from drainage systems, water pipe systems, various equipment in bottling halls, air of bottling halls, conveyors belts and oil lubricants, cracked floors and tiles of the filling hall [11] [92].

(a)



(c)



(b)



(d)

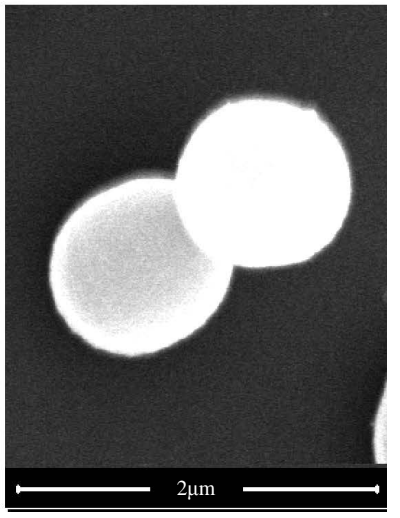

Figure 2. SEM Images of (a) - Pectinatus cerevisiiphilus, (b)Pectinatus frisingensis and (c) \& (d)-Megasphaera cerevisiae brewery isolates (images courtesy of A. Paradh). 
Pectinatus have also been reported in pitching yeast and $\mathrm{CO}_{2}$ recovery systems [91]. The isolation of Pectinatus has been mainly from beer filling halls and filling machines and prolonged survival of Pectinatus in biofilms formed in beer filling areas indicates that water may be a possible source of contamination [11]. Viable Pectinatus strains, although being anaerobic bacteria, have been found in aerosols around fillers of bottling machines indicating that air or other aerosols around fillers could be a possible source of contamination [91]. Survival of Pectinatus in aerobic environments of beer filling halls can be possible due to formation of biofilms with mixed populations of various micro-flora commonly occurring in brewery environments [93]. P. portalensis has been isolated from waste water of a winery [78] and recently P. brassicae has been isolated from a pickle waste water plant [80], suggesting that occurrence of Pectinatus species can be broadened from brewery environments to anaerobic and organic matter rich niches in food production and other beverage production environments.

Brewery related Pectinatus species are non-spore forming, motile rods with flagella attached laterally to one side of the cells. Young cells show an X shaped pattern formation during movement and old cells show slow snake like movement [72] [73] [76] [77]. For P. cerevisiiphilus and $P$. frisingensis growth occurs between $15^{\circ} \mathrm{C}$ $-40^{\circ} \mathrm{C}$ and optimum growth occurs at $30^{\circ} \mathrm{C}-32^{\circ} \mathrm{C}$ [72] [76] [77]. Growth of P. haikarae is inhibited at temperatures above $37^{\circ} \mathrm{C}$ and optimum growth occurs between $20^{\circ} \mathrm{C}-30^{\circ} \mathrm{C}$. P. frisingensis can maintain cellular homeostasis during sudden changes in temperature [94]. P. cerevisiiphilus when co-cultured with $S$. cerevisiae showed growth at $8^{\circ} \mathrm{C}$ and it also affects the growth of $S$. cerevisiae [95]. The $\mathrm{pH}$ range for growth of these bacteria lies between 3.5 and 8.0 and optimum growth occurs at 6.5 - 7.0 [72] [76] [77]. Pectinatus species can tolerate ethanol concentration up to $3.7 \%-4.4 \%$ (w/v) and growth is completely inhibited at ethanol concentration of $5.5 \%(\mathrm{w} / \mathrm{v})$ [73] [91]. P. cerevisiiphilus and $P$. frisingensis can grow at a dissolved oxygen concentration of 0.4 $0.8 \mathrm{mg} / \mathrm{L}$ and $P$. frisingensis showed better tolerance to dissolved oxygen compared to $P$. cerevisiiphilus [95]. The oxygen tolerance of $P$. cerevisiiphilus has been reported to improve with a decrease in temperature [96]. $P$ frisingensis is better adapted to acidic and thermal environments compared to other Pectinatus species [88]. $P$. frisingensis can metabolise a wider range of fermentable sugars but it cannot utilise ethanol, maltose and essential amino acids [76] [97]. P. cerevisiiphilus, $P$. frisingensis and $P$. haikarae are reported to have strong beer spoilage ability mainly in unpasteurised and low alcohol content beer [91]. The spoilage effects mainly include production of propionic acid, acetic acid, $\mathrm{H}_{2} \mathrm{~S}$, dimethyl sulphide (DMS), and methyl mercaptan. The rapid cell growth makes beer turbid and beer typically smells like rotten eggs due to production of sulphur compounds [88] [91].

\subsection{Megasphaera}

Genus Megasphaera, originally described by Rogosa [98], consists of five validly published species; $M$. elsdenii [98], M. cerevisiae [99], M. micronuciformis [84], M. paucivorans and M. sueciensis [77]. Megasphaera species have been isolated from a variety of different environments such as human clinical specimens, rumen gut flora and brewery environments [84] [100]. Important characteristics of beer spoilage Megasphaera species are shown in Table 2. At present the genus Megasphaera is comprised of three brewery associated species. Megasphaeracerevisiae [99] was the first brewery associated species, mainly representing low-alcohol beer spoiling cocci. M. cerevisiae was responsible for 3\% - 7\% of beer spoilage cases in Europe during the period 1980 to 2002, mainly in unpasteurised beer [93]. Later, two novel coccoid shaped bacteria were identified associated with beer spoilage and named M. paucivorans and M. sueciensis [77]. Spoilage effects of $M$. cerevisiae include turbidity and unpleasant odour, due to production of $\mathrm{H}_{2} \mathrm{~S}$ and short chain fatty acids. All Megasphaera species related to the brewery environment are strictly anaerobic, Gram negative, non-spore forming and non-motile [77] [99].

Brewery related Megasphaera species share common ecological niches with Pectinatus but are less widespread [77] [88] [89]. M. cerevisiae has been extensively studied as a contaminant of unpasteurised beer. M. cerevisiae has also been reported from brewery bottling hall biofilms and occasionally from pitching yeast and $\mathrm{CO}_{2}$ recovery systems [77]. Occurrence of $M$. paucivorans and $M$. sueceinsis has not been studied well but these species have been reported to be isolated from unpasteurised beer and other brewery environments [88].

Growth occurs in the temperature range $15^{\circ} \mathrm{C}-37^{\circ} \mathrm{C}$ and optimum growth is reported to be at $28^{\circ} \mathrm{C}$ [101]. No growth is observed at 10 and $45^{\circ} \mathrm{C}$ [77]. Megasphaera cerevisiae is limited to ethanol concentration of $2.1 \%$ $(\mathrm{w} / \mathrm{v})$ and its growth completely inhibited at a concentration of $4.2 \%(\mathrm{w} / \mathrm{v})$ [101]. Growth at normal beer $\mathrm{pH}$ has 
been detected but its growth is completely inhibited at pH 4.1 and above [77]. Beer spoilage ability of Megasphaera species is not as extensively studied compared to Pectinatus. Megasphaera species mainly affect low alcohol and unpasteurised beer producing turbidity and metabolic products such as butyric acid and minor amounts of acetic acid, valeric acid, caprioc acid and acetoin [88]. Considerable amounts of $\mathrm{H}_{2} \mathrm{~S}$ are produced in spoiled beer giving a very unpleasant odour [72] [101].

\subsection{Other Strictly Anaerobic Bacteria in Brewery Environments}

Other Gram negative, anaerobic beer spoilers phylogenetically related to Pectinatus and Megasphaera belong to genera Zymophilus, Selenomonas and Propionispira. Selenomonaslacticiflex and Propionispira are non-spore forming, motile rods and may lose mobility on repeated culturing Selenomonaslacticiflex and Propionispira are more sensitive to acidic environments than Pectinatus and Megasphaera and has been isolated from pitching yeast in Germany and Finland [89]. Selenomonaslacticiflexis have relatively high alcohol tolerance and can grow in beer at $4.5 \%(\mathrm{w} / \mathrm{v})$ alcohol. Selenomonaslacticiflexis can also grow at lower temperature of yeast storage [102]. Propionispira species are considered as potential beer spoilage bacteria [88]. Brewery related Propionispira have been reported in brewery waste lines and drainage systems which could be suggested as a source of contamination [88]. There is limited data available on beer spoilage ability of Propionispira species [102]. Z. raffinosivorans and $Z$. paucivorans have been isolated from pitching yeast but have never been implicated as causative agents for beer spoilage due to their inability to grow in beer [89].

\section{Detection of Gram Negative Beer Spoilage Bacteria}

Conventional methods for detection of spoilage microorganisms in beer and other beverages generally involves pre-enrichment of the sample with a non-selective medium, followed by enrichment on selective or differential agar [17].

For AAB bacteria Frateur's differential medium, AE medium, Reinforced AE medium and YPM medium have been described in the literature [20]. No single medium has been found to be effective in supporting growth of AAB. Rapid detection of AAB using real time PCR [103] Restriction fragment length polymorphism (RFLP) [104] [105], Amplified fragment length polymorphism (AFLP) [106], Denaturing gradient gel electrophoresis (DGGE) [106] and Fluorescent in situ hybridisation (FISH) [106] have been utilised for detection and characterisation.

Detection of Zymomonas in the brewery using MYPG (malt yeast extract glucose and peptone) agar supplemented with $50 \mathrm{ppm}$ actidione and 3\% ethanol or beer with $100 \mathrm{ppm}$ actidione has been reported [5]. For detection of Zymomonas in beer media supplemented with lead acetate (producing of black colonies) and Schiffs reagent (producing of purple colonies) has been documented [107]. PCR, Amplified ribosomal DNA restriction analysis (ARDA) method for rapid detection of Zymomonas at sub species level and primers specific for $23 \mathrm{~S}$ rRNA gene for detection Zymomonas species has also been developed [46].

For detection of Enterobacteriaceae in wort and yeast slurries the use of MacConkey agar supplemented with actidione (10 ppm) for suppression of yeasts is recommended by the European Brewing Convention [5]. However O. proteus grow comparatively slower on MacConkey agar [28]. Universal beer agar (UBA) with actidione has been used for wort samples and WLN agar has been used for enrichment of beer [28]. A PCR based method for specific detection and discrimination of $O$. proteus biogroup- 2 strains from $O$. proteus biogroup- 1 andother related microorganisms has been documented [66]. Characterisation of O. proteus biogroup-1 strains using automated ribotyping and PCR based methods has also been reported.

For Gram negative strictly anaerobic bacteria such as Pectinatus and Megasphaera, SMMP (Selective Medium for Megasphaera and Pectinatus), NBB medium, and MRS medium with several modification have been described [5] [88]. There are several rapid detection methods available for detection of these microorganisms based on techniques such as Immunoassay, Ribotyping, PCR based methods, RT PCR based methods, Florescence and Luminescence based molecular probes [17] [88] [108] [111]. Although several methods are available in brewing literature, the actual use in commercial brewing microbiological labs is still limited to conventional plating and a few rapid detection methods.

\section{Conclusions}

There is a small range of non-pathogenic beer spoilage bacteria which can survive, grow and spoil beer. Very 
few cases of beer spoilage have been reported in recent years due to high standards of hygiene and technological improvements within the brewing industry. However, due to food and beverage safety concerns, strict regulations regarding food and beverage production and maintaining high quality of products, beer spoilage microorganisms are of severe concern to breweries worldwide. Acetic Acid Bacteria such as Acetobacter and Gluconobacter were important beer spoilers. Due to implementation of effective cleaning and sanitation procedures in modern breweries and effective removal of oxygen from post fermentation processes, these bacteria are of minor importance in commercial brewing. However these bacteria are concern to dispense systems in pub breweries, public houses and cask conditioned beers [6]. Zymomonas is still a concern in primed cask condition beer and cider production. Brewery related Enterobactericeace serve as indicator microorganisms for the level of hygiene and sanitation.

Pectinatus and Megasphaera have been postulated to emerge due to high levels of hygiene and significant reduction in oxygen levels in beer and increased production of unpasteurised beer [102]. These microorganisms can cause serious damage to the brand image of the breweries as they are often detected sporadically in small packages (bottles, cans) and often in kegs, resulting in total recall of the batch in the supply chain. Pectinatus and Megasphaera are sensitive to routine cleaning agents used in breweries but they can survive and proliferate in biofilms dwelling the brewery environment eventually causing spoilage of beer. Detailed chapters on beer spoilage bacteria and technologies to reduce microbial spoilage can be found in the recently published book on Brewing Microbiology [112].

\section{References}

[1] Larson, E.L. and Morton, H.E. (1991) Alcohols. In: Block, S.S., Ed., Disinfection, Sterilization, and Preservation, 4th Edition, Lea and Febiger, Philadelphia, PA, 191-203.

[2] McDonnell, G. and Russell, A.D. (1999) Antiseptics and Disinfectants: Activity, Action, and Resistance. Clinical Microbiology Reviews, 12, 147-179.

[3] Simpson, W.J. and Smith, A.R.W. (1992) Factors Affecting Antibacterial Activity of Hop Compounds and Their Derivatives. Journal of Applied Bacteriology, 72, 327-334. http://dx.doi.org/10.1111/j.1365-2672.1992.tb01843.x

[4] Simpson, W.J. (1993) Ionophoric Action of ISO Trans-Humulone on Lactobacillus brevis. Journal of General Microbiology, 139, 1041-1045. http://dx.doi.org/10.1099/00221287-139-5-1041

[5] Jespersen, L. and Jakobsen, M. (1996) Specific Spoilage Organisms in Breweries and Laboratory Media for Their Detection. International Journal of Food Microbiology, 33, 139-155. http://dx.doi.org/10.1016/0168-1605(96)01154-3

[6] Sakamoto, K. and Konings, W.N. (2003) Beer Spoilage Bacteria and Hop Resistance. International Journal of Food Microbiology, 89, 105-124. http://dx.doi.org/10.1016/S0168-1605(03)00153-3

[7] Donhauser, S. and Jacob, F. (1988) Warumzählt Bier zu den reinstenLebensmitteln? Brauwelt, 128, 1452-1461.

[8] Dowhanick, T.M. (1994) Advances in Yeast and Contaminant Determination: The Future of the So Called "Rapid" Methods. Proceedings of J. De Clerck Chair VI, Leuven, 11-15 September 1994, 11-15.

[9] Menz, G., Aldred, P. and Vriesekoop, F. (2009) Pathogens in Beer. In: Preedy, V.R., Ed,, In Beer in Health and Disease Prevention, Academic Press, Amsterdam, 403-413. http://dx.doi.org/10.1016/B978-0-12-373891-2.00039-0

[10] Haakensen, M. and Ziola, B. (2008) Identification of Novel horA-Harbouring Bacteria Capable of Spoiling Beer. Canadian Journal of Microbiology, 54, 321-325. http://dx.doi.org/10.1139/W08-007

[11] Back, W., (2005) Brewery. In: Back, W., Ed., Colour Atlas and Handbook of Beverage Biology. Fachverlag Hans Carl, Nürnberg, 10-112.

[12] Suzuki, K., Asano, S., Iijima, K. and Kitamoto, K. (2008) Sake and Beer Spoilage Lactic Acid Bacteria-A Review. Journal of Institute of Brewing, 114, 209-223. http://dx.doi.org/10.1002/j.2050-0416.2008.tb00331.x

[13] Suzuki, K. (2011) 125th Anniversary Review: Microbiological Instability of Beer Caused by Spoilage Bacteria. Journal of the Institute of Brewing, 117, 131-155. http://dx.doi.org/10.1002/j.2050-0416.2011.tb00454.X

[14] Rainbow, C. (1981) Beer Spoilage Microorganisms. In: Pollock, J.R.A., Ed., Brewing Science, Academic Press, New York, Vol. 2, 491-550.

[15] Priest, F.G. and Campbell, I. (Eds.) (2003) Brewing Microbiology. 3rd Edition, Kluwer Academic/Plenum Publisher, New York, 1-399. http://dx.doi.org/10.1007/978-1-4419-9250-5

[16] Vaughan, A., O’Sullivan, T. and Van Sinderen, D. (2005) Enhancing the Microbiological Stability of Malt and BeerA Review. Journal of Institute of Brewing, 111, 355-371. http://dx.doi.org/10.1002/j.2050-0416.2005.tb00221.x

[17] Hill, A.E. (2009) Microbiological Stability of Beer. In: Bamforth, C., Ed., Beer: A Quality Perspective, Academic Press, Cambridge, 163-184. http://dx.doi.org/10.1016/b978-0-12-669201-3.00005-1 
[18] Gilliland, R.B. (1971) Yeast Classification. Journal of Institute of Brewing, 77, 276-284. http://dx.doi.org/10.1002/j.2050-0416.1971.tb06946.x

[19] Bokulich, N.A. and Bamforth, C.W. (2013) The Microbiology of Malting and Brewing. Microbiology and Molecular Biology Reviews, 77, 157-172. http://dx.doi.org/10.1128/MMBR.00060-12

[20] Quain, D. and Storgårds, E. (2009) The Extraordinary World of Biofilms. PloS Biology, 5, 2458-2461.

[21] Gonzalez, A., Hierro, N., Poblet, M., Mas, A. and Guillamon, J.M. (2005) Application of Molecular Methods to Demonstrate Species and Strain Evolution of Acetic Acid Bacteria Population during Wine Production. International Journal of Food Microbiology, 102, 295-304. http://dx.doi.org/10.1016/j.ijfoodmicro.2004.11.020

[22] Gupta, A., Singh, V.K., Qazi, G.N. and Kumar, A. (2001) Gluconobacter oxydans: Its Biotechnological Applications. Journal of Molecular Microbiology and Biotechnology, 3, 445-456.

[23] Bartowsky, E.J. and Henschke, P.A. (2008) Acetic Acid Bacteria Spoilage of Bottled Red Wine-A Review. International Journal of Food Microbiology, 125, 60-70. http://dx.doi.org/10.1016/j.ijfoodmicro.2007.10.016

[24] Ingledew, M.W. (1979) Effect of Bacterial Contaminants on Beer. A Review. Journal of American Society of Brewing Chemists, 37, 145-150.

[25] Magnus, C.A., Ingledew, M.W. and Casey, G. (1986) High-Gravity Brewing: Influence of High-Ethanol Beer on the Viability of Contaminating Brewery Bacteria. Journal of American Society of Brewing and Chemist, 44, 57-61.

[26] Van Vuuren, H.J.J. and Priest, F.G. (2003) Gram-Negative Brewery Bacteria. In: Priest, F.G. and Campbell, I., Eds., Brewing Microbiology, Springer US, 219-245. http://dx.doi.org/10.1007/978-1-4419-9250-5_6

[27] Asai, T. (1968) Acetic Acid Bacteria. Classification and Biochemical Activities. University of Tokyo Press, Baltimore, 103.

[28] Priest F.G. (2006) Microbiology and Microbial Control Methods in the Brewery. In: Priest, F.G. and Stewart, G.G., Eds., Handbook of Brewing, CRC Press, Boca Raton, 608-625.

[29] Cleenwerck, I., Vandemeulebroecke, K., Janssens, D. and Swings, J. (2002) Re-Examination of the Genus Acetobacter, with Descriptions of Acetobacter cerevisiae sp. nov. and Acetobacter malorum sp. nov. International Journal of Systematic and Evolutionary Microbiology, 52, 1551-1558. http://dx.doi.org/10.1099/00207713-52-5-1551

[30] Skerman, V.B.D., McGowan, V. and Sneath, P.H.A. (1980) Approved Lists of Bacterial Names. International Journal of Systematic Bacteriology, 30, 225-420. http://dx.doi.org/10.1099/00207713-30-1-225

[31] Spitaels, F., Wieme, A., Balzarini, T., Cleenwerck, I., Van Landschoot, A., De Vuyst, L. and Vandamme, P. (2014) Gluconobacter cerevisiae sp. nov., Isolated from the Brewery Environment. International Journal of Systematic and Evolutionary Microbiology, 64, 1134-1141. http://dx.doi.org/10.1099/ijs.0.059311-0

[32] Saeki, A., Taniguchi, M., Matsushita, K., Toyama, H., Theeragool, G., Lotong, N. and Adachi, O. (1997) Microbiological Aspects of Acetate Oxidation by Acetic Acid Bacteria, Unfavourable Phenomena in Vinegar Fermentation. Bioscience Biotechnology and Biochemistry, 61, 317-323. http://dx.doi.org/10.1271/bbb.61.317

[33] Matsushita, K., Toyama, H. and Adachi, O. (1994) Respiratory Chains and Bioenergetics of Acetic Acid Bacteria. Advances in Microbial Physiology, 36, 247-301. http://dx.doi.org/10.1016/S0065-2911(08)60181-2

[34] De Ley, J., Gillis, M. and Swings, J. (1984) Family VI. Acetobacteraceae. In: Krieg, N.R. and Holt, J.G., Eds., Bergey's Manual of Systematic Bacteriology, Vol. 1, Williams \& Wilkins, Baltimore, 267-278.

[35] Attwood, M.M., van Dijken, J.P. and Pronk, J.T. (1991) Glucose Metabolism and Gluconic Acid Production by Acetobacter diazotrophicus. Journal of Fermentation and Bioengineering, 72, 101-105.

http://dx.doi.org/10.1016/0922-338X(91)90317-A

[36] Back, W. (1994) Secondary Contamination in the Filling Area. Brauwelt International, 4, 326-328.

[37] Storgårds, E. (1997) Microbiological Quality of Draught Beer-Is There Reason for Concern? Proceedings of the European Brewing Convention Symposium Draught Beer, Packaging and Dispense, EBC Monograph XXV, Edinburgh, Verlag Hans Carl: Nürnberg, 92-103.

[38] Storgårds, E. (2000) Process Hygiene Control in Beer Production and Dispensing. Academic Dissertation, VTT Publication 410, Helsinki, 1-108.

[39] Van Vuuren, H.J.J, Loos, M.A., Louw, H.A. and Meisel, R. (1979) Distribution of Bacterial Contaminants in a South African Lager Brewery. Journal of Applied Bacteriology, 47, 421-424. http://dx.doi.org/10.1111/j.1365-2672.1979.tb01202.x

[40] Bokulich, N.A., Bamforth, C.W. and Mills, D.A. (2012) Brewhouse-Resident Microbiota Are Responsible for Multi-Stage Fermentation of American Coolship Ale. PLoS ONE, 7, e35507. http://dx.doi.org/10.1371/journal.pone.0035507

[41] Hornsey, I. (2013) Brewing. Royal Society of Chemistry, London. 
[42] Prust, C., Hoffmeister, M., Liesegang, H., Wiezer, A., Fricke, W.F., Ehrenreich, A. and Deppenmeier, U. (2005) Complete Genome Sequence of the Acetic Acid Bacterium Gluconobacter oxydans. Nature Biotechnology, 23, 195-200. http://dx.doi.org/10.1038/nbt1062

[43] Holt, J.G., Krieg, N.R., Sneath, P.H.A., Staley, J.T. and Williams, S.T. (1994) Genus Acetobacter and Gluconobacter. Bergey's Manual of Determinative Bacteriology. Williams and Wilkins, Baltimore, 71-84.

[44] Van Vuuren, H.J.J. (1996) Gram-Negative Spoilage Bacteria. In: Priest, F.G. and Campbell, I., Eds., Brewing Microbiology, Springer US, 163-191. http://dx.doi.org/10.1007/978-1-4757-4679-2_6

[45] Yang, S., Pappas, K.M., Hauser, L.J., Land, M.L., Chen, G.L., Hurst, G.B. and Brown, S.D. (2009) Improved Genome Annotation for Zymomonas mobilis. Nature Biotechnology, 27, 893-894. http://dx.doi.org/10.1038/nbt1009-893

[46] Coton, M., Laplace, J.M., Auffray, Y. and Coton, E. (2005) Polyphasic Study of Zymomonas mobilis Strains Revealing the Existence of a Novel Subspecies Z. mobilis subsp. francensis subsp. nov., Isolated from French Cider. International Journal of Systematic and Evolutionary Microbiology, 56, 121-125. http://dx.doi.org/10.1099/ijs.0.63732-0

[47] Chandel, A.K., Chandrasekhar, G., Radhika, K., Ravinder, R. and Ravindra, P. (2011) Bioconversion of Pentose Sugars into Ethanol: A Review and Future Directions. Biotechnology and Molecular Biology Reviews, 6, 8-20.

[48] Gírio, F.M., Fonseca, C., Carvalheiro, F., Duarte, L.C., Marques, S. and Bogel-Łukasik, R. (2010) Hemicelluloses for Fuel Ethanol: A Review. Bioresource Technology, 101, 4775-4800. http://dx.doi.org/10.1016/j.biortech.2010.01.088

[49] Shimwell, J.L. (1936) Study of a New Species of Acetobacter (A. capsulatum) Producing Ropiness in Beer and Beer-Wort. Journal of the Institute of Brewing, 42, 585-595. http://dx.doi.org/10.1002/j.2050-0416.1936.tb05704.x

[50] Millis, N.F. (1956) A Study of the Cider-Sickness Bacillus-A New Variety of Zymomonas anaerobia. Journal of General Microbiology, 15, 521-528. http://dx.doi.org/10.1099/00221287-15-3-521

[51] De Ley, J. and Swings, J. (1976) Phenotypic Description, Numerical Analysis, and Proposal for an Improved Taxonomy and Nomenclature of the Genus Zymomonas Kluyver and van Niel 1936. International Journal of Systematic Bacteriology, 26, 146-157. http://dx.doi.org/10.1099/00207713-26-2-146

[52] Lindner, P. (1928) Atlas d. Mikrosk. Grundl. der Garungsk. 3 Aufl. 2. Cited by Bergey’s Manual of Determinative Bacteriology (1948) 6th ed. edited by Breed, R.S., Murray, E.G.D. and Hitchens, A.P. London: BalliGre, Tindall and Cox.

[53] Coton, E. and Coton, M. (2003) Microbiological Origin of "Framboisé" in French Ciders. Journal of the Institute of Brewing, 109, 299-304. http://dx.doi.org/10.1002/j.2050-0416.2003.tb00601.x

[54] Dads, M.J.S. and Martin, P.A. (1978) The Genus Zymomonas-A Review. Journal of the Institute of Brewing, 79, 386391. http://dx.doi.org/10.1002/j.2050-0416.1973.tb03554.X

[55] Seo, J.S., Chong, H., Park, H.S., Yoon, K.O., Jung, C., Kim, J.J. and Kang, H.S. (2004) The Genome Sequence of the Ethanologenic Bacterium Zymomonas mobilis ZM4. Nature Biotechnology, 23, 63-68. http://dx.doi.org/10.1038/nbt1045

[56] Lapage, S.P. (1979) Proposal of Enterobacteraceae nom. nov. as a Substitute for the Illegitimate but Conserved Name Enterobacteriaceae Rahn 1937: Request for an Opinion. International Journal of Systematic Bacteriology, 29, 265-266. http://dx.doi.org/10.1099/00207713-29-3-265

[57] Rahn, O. (1937) New Principles for the Classification of Bacteria. Zentralblatt fur Bakteriologie, Parasitenkunde, Infektionskrankheiten und Hygiene, 96, 273-286.

[58] APHA (1998) Standard Methods for the Examination of Water and Wastewater. American Public Health Association, Washington DC.

[59] Priest, F.G., Cowbourne, M.A. and Hough, J.S. (1974) Wort Enterobacteria-A Review. Journal of Institute of Brewing, 80, 342-356. http://dx.doi.org/10.1002/j.2050-0416.1974.tb03629.x

[60] Priest, F.G. and Barker, M. (2010) Gram-Negative Bacteria Associated with Brewery Yeasts: Reclassification of $O b-$ esumbacterium proteus Biogroup 2 as Shimwellia pseudoproteus gen. nov., sp. nov., and Transfer of Escherichia blattae to Shimwellia blattae comb. nov. International Journal of Systematic and Evolutionary Microbiology, 60, 828-833. http://dx.doi.org/10.1099/ijs.0.013458-0

[61] Shimwell, J.L. (1963) Obesumbacterium gen. nov. Brewers’ Journal, 99, 759-760.

[62] Shimwell, J.L. (1964) Obesumbacterium, a New Genus for the Inclusion of "Flavobacterium proteus”. Journal of the Institute of Brewing, 70, 247-248. http://dx.doi.org/10.1002/j.2050-0416.1964.tb01988.x

[63] Priest, F.G., Somerville, H.J., Cole, J.A. and Hough, J.S. (1973) The Taxonomic Position of Obesumbacterium proteus, a Common Brewery Contaminant. Journal of General Microbiology, 75, 295-307. http://dx.doi.org/10.1099/00221287-75-2-295

[64] Farmer, J.J. (1984) Other Genera of the Family Enterobacteriaceae. In: Krieg, N.R. and Holt, J.G., Eds., Bergey’s Manual of Systematic Bacteriology, Williams and Wilkins, Baltimore. 
[65] Smith, N.A. (1994) Cambridge Prize Lecture Nitrate Reduction and n-Nitrosation in Brewing. Journal of the Institute of Brewing, 100, 347-355. http://dx.doi.org/10.1002/j.2050-0416.1994.tb00835.x

[66] Maugueret, T.J. and Walker, S.L. (2002) Rapid Detection of Obesumbacterium proteus from Yeast and Wort Using Polymerase Chain Reaction. Letters in Applied Microbiology, 35, 281-284. http://dx.doi.org/10.1046/j.1472-765X.2002.01179.x

[67] Prest, A.G., Hammond, J.R. and Stewart, G.S. (1994) Biochemical and Molecular Characterization of Obesumbacterium proteus, a Common Contaminant of Brewing Yeasts. Applied and Environmental Microbiology, 60, 1635-1640.

[68] Blomqvist, K., Nikkola, M., Lehtovaara, P., Suihko, M.L., Airaksinen, U., Stråby, K.B. and Penttilä, M.E. (1993) Characterization of the Genes of the 2,3-Butanediol Operons from Klebsiella terrigena and Enterobacter aerogenes. Journal of Bacteriology, 175, 1392-1404.

[69] Van Vuuren, H.J.J. (1996) Gram-Negative Spoilage Bacteria. In: Priest, F.G. and Campbell, I., Eds., Brewing Micobiology, 2nd Edition, Elsevier, London, 163-191. http://dx.doi.org/10.1007/978-1-4757-4679-2 6

[70] Hamze, M., Mergaert, J., Van Vuuren, H.J.J., Gavini, F., Beji, A., Izard, D. and Kersters, K. (1991) Rahnella aquatilis, a Potential Contaminant in Lager Beer Breweries. International Journal of Food Microbiology, 13, 63-68. http://dx.doi.org/10.1016/0168-1605(91)90137-E

[71] van Vuuren, H.J.J., Cosser, K. and Prior, B.A. (1980) The Influence of Enterobacter agglomerans on Beer Flavour. Journal of the Institute of Brewing, 86, 31-33. http://dx.doi.org/10.1002/j.2050-0416.1980.tb03952.x

[72] Lee, S.Y., Mabee, M.S. and Jangaard, N.O. (1978) Pectinatus, a New Genus of the Family Bacteriodaceae. International Journal of Systematic Bacteriology, 28, 582-594. http://dx.doi.org/10.1099/00207713-28-4-582

[73] Haikara, A., Enari, T.M. and Lounatmaa, K. (1981) The Genus Pectinatus, a New Group of Anaerobic Beer Spoilage Bacteria. Proceedings of European Brewing Convention Congress, Copenhagen, IRL Press, Oxford, 229-240.

[74] Takahashi, N. (1983) Presumed Pectinatus Strain Isolated from Japanese Beer. Bulletin of Brewing Science, 28, 11-14.

[75] Hage, T. and Wold, K. (2003) Practical Experiences on the Combat of a Major Pectinatus and Megasphaera Infection with the Help of TaqMan Realtime-PCR. Proceedings of the 29th EBC Congress, Fachverlag Hans Carl., Dublin, Nürnberg, Germany, 1145-1148.

[76] Schleifer, K.H., Leuteritz, M., Weiss, N., Ludwig, W., Kirchhof, G. and Seidel, R.H. (1990) Taxonomic Study of Anaerobic, Gram-Negative, Rod-Shaped Bacteria from Breweries: Emended Description of Pectinatus cerevisiiphilus and Description of Pectinatus frisingensis sp. nov., Selenomonas lacticifex sp. nov., Zymophilus raffinosivorans gen. nov., sp. nov., and Zymophilus paucivorans sp. nov. International Journal of Systematic and Evolutionary Microbiology, 40, 19-27. http://dx.doi.org/10.1099/00207713-40-1-19

[77] Juvonen, R. and Suihko, M.L. (2006) Megasphaera paucivorans sp. nov., Megasphaera sueciensis sp. nov. and Pectinatus haikarae sp. nov., Isolated from Brewery Samples, and Emended Description of the Genus Pectinatus. International Journal of Systematic Evolutionary Microbiology, 56, 695-702. http://dx.doi.org/10.1099/ijs.0.63699-0

[78] Gonzalez, J.M., Jurado, V., Laiz, L., Zimmermann, J., Hermosin, B. and Saiz-Jimenez, C. (2004) Pectinatus portalensis nov. sp., a Relatively Fast-Growing, Coccoidal, Novel Pectinatus Species Isolated from a Wastewater Treatment Plant. Antonie van Leeuwenhoek, 86, 241-247. http://dx.doi.org/10.1023/B:ANTO.0000047931.55259.33

[79] Vereecke, C. and Arahal, D.R. (2008) The Status of the Species Pectinatus portalensis Gonzalez et al. 2005. Request for an Opinion. International Journal of Systematic and Evolutionary Microbiology, 58, 1507. http://dx.doi.org/10.1099/ijs.0.65854-0

[80] Zhang, W.W., Fang, M.X., Tan, H.Q., Zhang, X.Q., Wu, M. and Zhu, X.F. (2012) Pectinatus brassicae sp. nov., a Gram-Negative, Anaerobic Bacterium Isolated from Salty Wastewater. International Journal of Systematic and Evolutionary Microbiology, 62, 2145-2149. http://dx.doi.org/10.1099/ijs.0.032144-0

[81] Caldwell, J.M., Juvonen, R., Brown, J. and Breidt, F. (2013) Pectinatus sottacetonis sp. nov., Isolated from a Commercial Pickle Spoilage Tank. International Journal of Systematic and Evolutionary Microbiology, 63, 3609-3616. http://dx.doi.org/10.1099/ijs.0.047886-0

[82] Willems, A. and Collins, M.D. (1995) Phylogenetic Placement of Dialister pneumosintes (Formerly Bacteroides pneumosintes) within the Sporomusa Sub-Branch of the Clostridium Subphylum of the Gram-Positive Bacteria. International Journal of Systematic Bacteriology, 45, 403-405. http://dx.doi.org/10.1099/00207713-45-2-403

[83] Strömpl, C., Tindall, B.J., Jarvis, G.N., Lünsdorf, H., Moore, E.R. and Hippe, H. (1999) A Re-Evaluation of the Taxonomy of the Genus Anaerovibrio, with the Reclassification of Anaerovibrio glycerini as Anaerosinus glycerini gen. nov., comb. nov., and Anaerovibrio burkinabensis as Anaeroarcus burkinensis [corrig.] gen. nov., comb. nov. International Journal of Systematic and Evolutionary Microbiology, 49, 1861-1872.

[84] Marchandin, H., Jumas-Bilak, E., Gay, B., Teyssier, C., Jean-Pierre, H., Siméon de Buochberg, M., Carrière, C. and Carlier, J.P. (2003) Phylogenetic Analysis of Some Sporomusa Sub-Branch Members Isolated from Human Clinical Specimens: Description of Megasphaera micronuciformis sp. nov. International Journal of Systematic and Evolutionary Microbiology, 53, 547-553. http://dx.doi.org/10.1099/ijs.0.02378-0 
[85] Marchandin, H., Teyssier, C., Campos, J., Jean-Pierre, H., Roger, F., Gay, B., Carlier, J.-P. and Jumas-Bilak, E. (2009) Negativicoccus succinicivorans gen. Nov., sp. Nov., Isolated from Human Clinical Samples, Emended Description of the Family Veillonellaceae and Description of Negativicutes Classis nov., Selenomonadales ord. nov. and Acidaminococcaceae fam. nov. in the Bacterial Phylum Firmicutes. International Journal of Systematic and Evolutionary Microbiology, 60, 1271-1279. http://dx.doi.org/10.1099/ijs.0.013102-0

[86] Rogosa, M. (1971) Transfer of Peptostreptococcus elsdenii Gutierrez et al. to a New Genus, Megasphaera [M. elsdenii (Gutierrez et al.) comb. nov.]. International Journal of Systematic Bacteriology, 21, 187-189. http://dx.doi.org/10.1099/00207713-21-2-187

[87] Chaban, B., Deneer, H., Dowgiert, T., Hymers, J. and Ziola, B. (2005) The Flagellin Gene and Protein from the Brewing Spoilage Bacteria Pectinatus cerevisiiphilus and Pectinatus frisingensis. Canadian Journal of Microbiology, 51, 863-874. http://dx.doi.org/10.1139/w05-076

[88] Juvonen, R. (2009) DNA-Based Detection and Characterisation of Strictly Anaerobic Beer-Spoilage Bacteria. VTT Publications 723, Helsinki, 1-140.

[89] Suzuki, K., Asano, S., Iijima, K. and Kitamoto, K. (2008) Sake and Beer Spoilage Lactic Acid Bacteria-A Review. Journal of the Institute of Brewing, 114, 209-223. http://dx.doi.org/10.1002/j.2050-0416.2008.tb00331.x

[90] Motoyama, Y., Ogata, T. and Sakai, K. (1998) Characterization of Pectinatus cerevisiiphilus and P. frisingensis by Ribotyping. Journal of American Society of Brewing Chemists, 56, 19-23.

[91] Haikara, A. and Helander, I. (2006) Pectinatus, Megasphaera and Zymophilus. In: Dworkin, M., Falkow, S., Rosenberg, E., Schleifer, K.H. and Stackebrandt, E., Eds., The Prokaryotes, Vol. 4, Springer-Verlag, New York, 965-981. http://dx.doi.org/10.1007/0-387-30744-3_32

[92] Motoyama, Y. (2003) The Study on Strictly Anaerobic Bacteria Capable of Spoiling Beer. PhD Thesis, Tokyo University, Tokyo.

[93] Back, W., Breu, S. and Weigand, C. (1988) Infektionsursachen im jahre 1987. Brauwelt, 178, 1358-1362.

[94] Chihib, N.E. and Tholozan, J.L. (1999) Effect of Rapid Cooling and Acidic pH on Cellular Homeostasis of Pectinatus frisingensis, a Strictly Anaerobic Beer-Spoilage Bacterium. International Journal of Food Microbiology, 48, 191-202. http://dx.doi.org/10.1016/S0168-1605(99)00046-X

[95] Chowdhury, I., Watier, D., Leguerinel, I. and Hornez, J.P. (1997) Effect of Pectinatus cerevisiiphilus on Saccharomyces cerevisiae Concerning Its Growth and Alcohol Production in Wort Medium. Journal of Food Microbiology, 14, 265-272. http://dx.doi.org/10.1006/fmic.1996.0092

[96] Flahaut, S., Tierny, Y., Watier, D., Hornez, J.P. and Jeanfils, J. (2000) Impact of Thermal Variations on Biochemical and Physiological Traits in Pectinatus sp. International Journal of Food Microbiology, 55, 53-61. http://dx.doi.org/10.1016/S0168-1605(00)00194-X

[97] Tholozan, J.L., Membré, J.M. and Kubaczka, M. (1996) Effects of Culture Conditions on Pectinatus cerevisiiphilus and Pectinatus frisingensis Metabolism: A Physiological and Statistical Approach. Journal of Applied Bacteriology, 80, 418-424. http://dx.doi.org/10.1111/j.1365-2672.1996.tb03237.x

[98] Rogosa, M. (1971) Transfer of Peptostreptococcus elsdenii Gutierrez et al. to a New Genus, Megasphaera [M. elsdenii (Gutierrez et al.) comb. nov.]. International Journal of Systematic Bacteriology, 21, 187-189. http://dx.doi.org/10.1099/00207713-21-2-187

[99] Engelmann, U. and Weiss, N. (1985) Megasphaera cerevisiae sp. nov.: A New Gram-Negative Obligately Anaerobic Coccus Isolated from Spoiled Beer. Journal of Systematic and Applied Microbiology, 6, 287-290. http://dx.doi.org/10.1016/S0723-2020(85)80033-3

[100] Zozaya-Hinchliffe, M., Martin, D.H. and Ferris, M.J. (2008) Prevalence and Abundance of Uncultivated Megasphaera-Like Bacteria in the Human Vaginal Environment. Applied and Environmental Microbiology, 74, 1656-1659. http://dx.doi.org/10.1128/AEM.02127-07

[101] Haikara, A. and Lounatmaa, K. (1987) Characterization of Megasphaera sp., a New Anaerobic Beer Spoilage Coccus. Proceedings of European Brewing Convention Congress, Madrid, IRL Press, Oxford, 473-480.

[102] Juvonen, R. (2015) Strictlyanaerobic Beer Spoilage Bacteria. In: Hill, A.E., Ed., Brewing Microbiology: Managing Microbes, Ensuring Quality and Valorising Waste, Wood Head Publication, Cambridge, 195-214. http://dx.doi.org/10.1016/B978-1-78242-331-7.00009-5

[103] Torija, M.J., Mateo, E., Guillamón, J.M. and Mas, A. (2010) Identification and Quantification of Acetic Acid Bacteria in Wine and Vinegar by TaqMan-MGB Probes. Food Microbiology, 27, 257-265. http://dx.doi.org/10.1016/j.fm.2009.10.001

[104] Ruiz, A., Poblet, M., Mas, A. and Guillamon, J.M. (2000) Identification of Acetic Acid Bacteria by RFLP of PCRAmplified 16S rDNA and 16S-23S rDNA Intergenic Spacer. International Journal of Systematic and Evolutionary Microbiology, 50, 1981-1987. http://dx.doi.org/10.1099/00207713-50-6-1981 
[105] Nanda, K., Taniguchi, M., Ujike, S., Ishihara, N., Mori, H., Ono, H. and Murooka, Y. (2001) Characterization of Acetic Acid Bacteria in Traditional Acetic Acid Fermentation of Rice Vinegar (Komesu) and Unpolished Rice Vinegar (Kurosu) Produced in Japan. Applied and Environmental Microbiology, 67, 986-990. http://dx.doi.org/10.1128/AEM.67.2.986-990.2001

[106] Cleenwerck, I., de Wachter, M., Gonzalez, A., de Vuyst, L. and de Vos, P. (2009) Differentiation of Species of the Family Acetobacteraceae by AFLP DNA Fingerprinting: Gluconacetobacter kombuchae Is a Later Heterotypic Synonym of Gluconacetobacter hansenii. International Journal of Systematic and Evolutionary Microbiology, 59, 17711786. http://dx.doi.org/10.1099/ijs.0.005157-0

[107] De Vero, L., Gala, E., Gullo, M., Solieri, L., Landi, S. and Giudici, P. (2006) Application of Denaturing Gradient Gel Electrophoresis (DGGE) Analysis to Evaluate Acetic Acid Bacteria in Traditional Balsamic Vinegar. Food Microbiology, 23, 809-813. http://dx.doi.org/10.1016/j.fm.2006.01.006

[108] Franke-Whittle, I.H., O’Shea, M.G., Leonard, G.J. and Sly, L.I. (2005) Design, Development, and Use of Molecular Primers and Probes for the Detection of Gluconacetobacter Species in the Pink Sugarcane Mealy Bug. Microbial Ecology, 50, 128-139. http://dx.doi.org/10.1007/s00248-004-0138-z

[109] Woodward, J.D. (1982) Detection of Zymomonas. Journal of the Institute of Brewing, 88, 84-85. http://dx.doi.org/10.1002/j.2050-0416.1982.tb04076.x

[110] Paradh, A.D., Mitchell, W.J. and Hill, A.E. (2011) Occurrence of Pectinatus and Megasphaera in the Major UK Breweries. Journal of the Institute of Brewing, 117, 498-506. http://dx.doi.org/10.1002/j.2050-0416.2011.tb00497.x

[111] Paradh, A.D., Hill, A.E. and Mitchell, W.J. (2014) Detection of Beer Spoilage Bacteria Pectinatus and Megasphaera with Acridinium Ester Labelled DNA Probes Using a Hybridisation Protection Assay. Journal of Microbiological Methods, 96, 25-34. http://dx.doi.org/10.1016/j.mimet.2013.10.014

[112] Hill A.E., Ed. (2015) Brewing Microbiology: Managing Microbes, Ensuring Quality and Valorising Waste. Wood Head Publication, Cambridge. 